\title{
Investigating caspases and other markers of apoptosis in ITP
}

\author{
Oliver Speer • Markus Schmugge
}

Received: 28 October 2009 / Accepted: 1 December 2009/Published online: 22 April 2010

(C) The Author(s) 2010. This article is published with open access at Springerlink.com

Apoptosis is the main mechanism that regulates cell life span and the elimination of damaged or infected nucleated cells. Although platelets are enucleate cells, they express at least part of the apoptotic machinery known from nucleated cells. In addition, they have been observed to undergo apoptotic-like events. This has been demonstrated by the activation and translocation of $\mathrm{Bcl}-2$ family members, cytochrome $c$ release, activation of caspase-9 and of caspase-3 $[1-10]$. These observations indicate that platelets contain the essential components needed to undergo programmed cell death executed in the cytoplasm. Recently, in a murine model of ITP, it has been shown that apoptotic-like processes can be induced by anti-platelet antibodies: injection of anti-GPIIb antibodies caused apoptotic-like events as well as profound thrombocytopenia [7, 11-14].In this murine ITP model, IVIg treatment was able to decrease the apoptotic-like events and to improve the low platelet count [7, 11-13].

As no such study has been performed in paediatric ITP so far, we started to investigate whether in children with primary ITP, an enhanced expression of markers of apoptotic processes can be found. Furthermore, we are interested to see if such markers correlate to platelet count and most important to clinical symptoms and if they decrease after IVIg treatment.

So far, we have shown in a limited number of patients that caspase- 3 is activated in $40 \%$ of the platelets in patients with primary ITP and decreases to $10 \%$ after IVIg treatment

\footnotetext{
O. Speer $(\bowtie) \cdot$ M. Schmugge

University Children's Hospital Zürich,

Zürich, Switzerland

e-mail: oliver.speer@kispi.uzh.ch

M. Schmugge

e-mail: markus.schmugge@kispi.uzh.ch
}

([15], manuscript in preparation). In parallel to caspase-3 activation also bleeding signs decreased after IVIg therapy. In ongoing studies, we investigate caspase-3, caspase-9, caspase-8, PS-exposure and mitochondrial membrane potential by flow cytometry and caspases by Western blot. We further will develop an immuno-fluorescence microscopy protocol for the detection and quantification of activated caspases in bone marrow smears. Investigating and comparing levels of activated caspases and other signs of apoptosis in platelets and bone marrow samples is important to understand the initiation of apoptotic processes in platelets, whether apoptosis is already triggered in bone marrow or only in platelets in ITP patients. Furthermore, it is important to understand whether apoptosis might contribute to the destruction of platelets in ITP patients.

To increase patient numbers, we invite other clinicians or laboratories treating respectively investigating ITP to collaborate with us.

Open Access This article is distributed under the terms of the Creative Commons Attribution Noncommercial License which permits any noncommercial use, distribution, and reproduction in any medium, provided the original author(s) and source are credited.

\section{References}

1. Leytin $\mathrm{V}$ et al (2007) Higher thrombin concentrations are required to induce platelet apoptosis than to induce platelet activation. Br J Haematol 136(5):762-764

2. Leytin V et al (2009) Mitochondrial control of platelet apoptosis: effect of cyclosporin A, an inhibitor of the mitochondrial permeability transition pore. Lab Invest 89(4):374-384

3. Leytin V et al (2008) Platelet activation and apoptosis are different phenomena: evidence from the sequential dynamics and the 
magnitude of responses during platelet storage. Br J Haematol 142 (3):494-497

4. Leytin V et al (2006) Thrombin-triggered platelet apoptosis. J Thromb Haemost 4(12):2656-2663

5. Leytin V et al (2004) Pathologic high shear stress induces apoptosis events in human platelets. Biochem Biophys Res Commun 320(2):303-310

6. Leytin V, Freedman J (2003) Platelet apoptosis in stored platelet concentrates and other models. Transfus Apher Sci 28(3):285295

7. Leytin V et al (2006) Intravenous immunoglobulin inhibits anti-glycoprotein IIb-induced platelet apoptosis in a murine model of immune thrombocytopenia. $\mathrm{Br} \mathrm{J}$ Haematol 133 (1):78-82

8. Mason KD et al (2007) Programmed anuclear cell death delimits platelet life span. Cell 128(6):1173-1186

9. Boing AN et al (2008) Platelet microparticles contain active caspase 3. Platelets 19(2):96-103
10. Lopez JJ et al (2008) Thrombin induces activation and translocation of Bid, Bax and Bak to the mitochondria in human platelets. $\mathrm{J}$ Thromb Haemost 6(10):1780-1788

11. Song $\mathrm{S}$ et al (2003) Monoclonal $\mathrm{IgG}$ can ameliorate immune thrombocytopenia in a murine model of ITP: an alternative to IVIG. Blood 101(9):3708-3713

12. Siragam V et al (2005) Can antibodies with specificity for soluble antigens mimic the therapeutic effects of intravenous IgG in the treatment of autoimmune disease? J Clin Invest 115(1):155-160

13. Crow AR et al (2003) IVIG induces dose-dependent amelioration of ITP in rodent models. Blood 101(4):1658-1659, Author reply 1659

14. Piguet PF, Vesin C (2002) Modulation of platelet caspases and life-span by anti-platelet antibodies in mice. Eur J Haematol 68 (5):253-261

15. Speer O et al (2009) Apoptosis in platelets from pediatric patients with acute immune thrombocytopenic purpura (ITP) ist ameliorated by IVIg, ASH annual meeting supplement. Blood 112 (11):3417 